\title{
Comparative analysis of risks which are accompanied by the use of typical and boundary gases concentrations for the diagnostics of high voltage transformers
}

\section{Oleg Shutenko ${ }^{1}$,}

\section{Olena Proskurnia ${ }^{2}$,}

Volodymyr Abramov ${ }^{3}$

${ }^{1}$ Department of "Electric Power Transmission" National Technical University

"Kharkiv Polytechnic Institute"

Kharkiv, Ukraine

Email: o.v.shutenko@gmail.com

\author{
2 "Business Administration and \\ Personnel Management Department”, \\ National Technical University \\ "Kharkiv Polytechnic Institute" \\ Kharkiv, Ukraine \\ Email:proskurniaolena@gmail.com \\ ${ }^{3}$ Department "High Voltage Engineering and \\ Electrophysics", \\ National Technical University of Ukraine \\ "Igor Sicorsky Kyiv Polytechnic Institute", \\ Kyiv, Ukraine \\ Email:vbabramov.main@gmail.com
}

The aim of the scientific research provided in the article is to increase the operational reliability of high-voltage power transformers by reducing the possible risks when diagnosing high-voltage equipment based on the analysis of gases dissolved in oil. We described the method for determining the boundary (typical) gas concentrations by the integral function method, which is recommended by some existing standards, and the author's method for determining the boundary concentrations of gases ensuring a minimum of possible economic damage in case of taking erroneous decisions. The analysis of boundary concentrations of gases obtained by the method of integral functions and the method of minimum risk showed that boundary values differ significantly for the same data, depending on the method of determination. To determine the reliability of decision-making we used a comparative analysis of risk values that may arise while making a diagnosis of high-voltage transformers based on the analysis of gases dissolved in oil, the boundary values of gas concentrations obtained by the integral function method and the minimum risk method, as well as the boundary values of gas concentrations regulated by known international and national standards were used.

The study has revealed that the use of typical values of gas concentrations obtained by integrated distribution functions is accompanied by one of the highest risk values. The lowest risk value is provided by the boundary concentrations obtained by the minimum risk method. The method proposed for determining the boundary values of gas concentrations, taking into account the influence of the most relevant factors, allows significantly lower the values of possible risks and consequently can increase the operational reliability of high-voltage transformers, especially those that are used outside the normative service life.

Keywords: diagnostics, transformers, analysis of dissolved gases, boundary and typical concentrations, integral distribution functions, minimum risk method, probabilities of erroneous and correct decisions 


\section{INTRODUCTION}

Electric power industry is the basic branch of the economy of any state, practically the entire infrastructure of modern civilization depends on its functioning. In connection with this, ensuring the reliability of high-voltage equipment, especially the one that operates outside the normative service life, is an actual and practically significant task. Currently, one of the methods of non-destructive diagnostics, which has found wide application in almost all countries, is the analysis of dissolved gases in oil (DGA). This method allows to detect up to $80 \%$ of all defects in oil-filled equipment. In most known standards [1-5], the interpretation of DGA results as a primary indication of the presence of a defect uses an excess of gas concentrations, some values called boundary or typical values. In some standards $[4,5]$ for the boundary gas concentration a $90-95 \%$ point is taken for the integral concentration distribution function obtained for 100 or more units of the same type of defect-free equipment. However, according to the method of determination and in terms of its physical nature, the values obtained are not boundary values, but typical concentrations. Therefore, they are the maximum concentrations of gases that can be detected in 90 to $95 \%$ of the equipment from the total quantity that does not show signs of a defect. Boundary concentrations mean the separation of two states of defective and defect-free. They cannot be determined only on the basis of a statistical analysis of the results of DGA obtained from a normally operating equipment. As noted in [1], the identification of boundary and typical concentrations is erroneous. In this connection, an objective necessity arises to develop a method that would allow us to determine the boundary concentrations of gases dissolved in oil, taking into account the influence of the most significant factors and the subsequent evaluation of the reliability of the decisions taken. At present, a large number of studies have been devoted to the determination of the boundary concentrations of gases as a key indicator of the risks and a failure of a transformer [6-10]. At the same time, different approaches are used to determine them. So in [6] it is suggested to choose the limiting level $F x$ taking into account the failure rate for this type of equipment and the bound- ary values to be determined taking into account the most significant factors. In [7] the boundary concentrations were determined on the basis of the Neumann-Pearson criterion, in [8] a method based on the Bayesian rule for the construction of boundaries for the partition of the classes of states was used. In [9-10] boundary values of gas concentration were determined by the minimum risk method for transformers of a leaky design, filled with different grades of oils. However, despite a considerable volume of publications, a comparative analysis of the reliability of decision-making, when using the boundary values of gas concentrations that were obtained by different methods, was not performed, which was the reason for writing this article.

\section{DETERMINATION OF TYPICAL GAS CONCENTRATIONS BASED ON ANALYSIS OF INTEGRAL DISTRIBUTION FUNCTIONS}

To compare the risk values using typical and boundary values of gas concentrations, to diagnose oil-filled equipment based on DGA results, typical values of gas concentrations were determined. As initial data, the results of DGA were used for 133 serviceable transformers with a rated power of 25 MVA/110 kV, type TRDN (two-winding transformer whose low-voltage winding is split) filled with oil of mark TKp (transformer oil obtained from low-sulfur naphthenic oils by the method of acid-base cleaning) [10]. These transformers are in operation for more than 25 years. The typical concentration of any gas was such a value below which the concentration of the gas in $90 \%$ of the total number of transformers surveyed turns out. Typical concentrations were determined from the integral distribution functions $\left(F_{i}\right)$ as follows $[4,5]$ :

1. The measured concentrations for each gas over all the transformers were broken into $L$ intervals (Sturgess's formula was used to determine the number of intervals):

$$
L=1+3.322 \lg N,
$$

where $N$ is volume of sampling values.

2. At each interval, the probability was found of the sampling values to fall within a given interval: 


$$
P_{L i}=\frac{n_{L i}}{N}
$$

where $n_{L i}$ is number of values in a given interval.

3. The values of the integral distribution function with allowance for (2) were obtained as:

$$
F_{L i}=\sum_{i=1}^{i=k} P_{L i}
$$

where $k<L$.

4. A typical concentration for each gas was determined at $F_{L i}=0.9$, graphically see Fig. 1 . The results of the calculation are given in Table 1.

\section{DETERMINATION OF THE BOUNDARY} VALUES OF GAS CONCENTRATIONS BY THE MINIMUM RISK METHOD

The studies carried out in [9-11] have shown that the distribution of gas concentrations in both defect-free transformers and transformers with de- veloping defects can be described by the Weibull distribution with the density:

$$
p(x ; \alpha, \beta)=\frac{\beta}{\alpha^{\beta}} \cdot x^{\beta-1} \cdot e^{-\left(\frac{x}{\alpha}\right)^{\beta}},
$$

where $\alpha$ is scale parameter and $\beta$ is shape parameter.

Values of the scale and shape parameters for serviceable transformers of leaky design TRDN $25 \mathrm{MVA}, 110 \mathrm{kV}$ and for transformers with developing defects [10] are given in Table 2.

Figure 2 shows the densities of theoretical Weibull distributions for ethylene concentrations for serviceable and defective transformers. Analysing Fig. 2, it is easy to see that the Weibull density distributions for the defect-free and defect states of the transformers intersect. And this means that it is in principle impossible to determine the boundary values that would not give wrong decisions.

Since in the diagnosis of the state of high-voltage power transformers the price of error of the

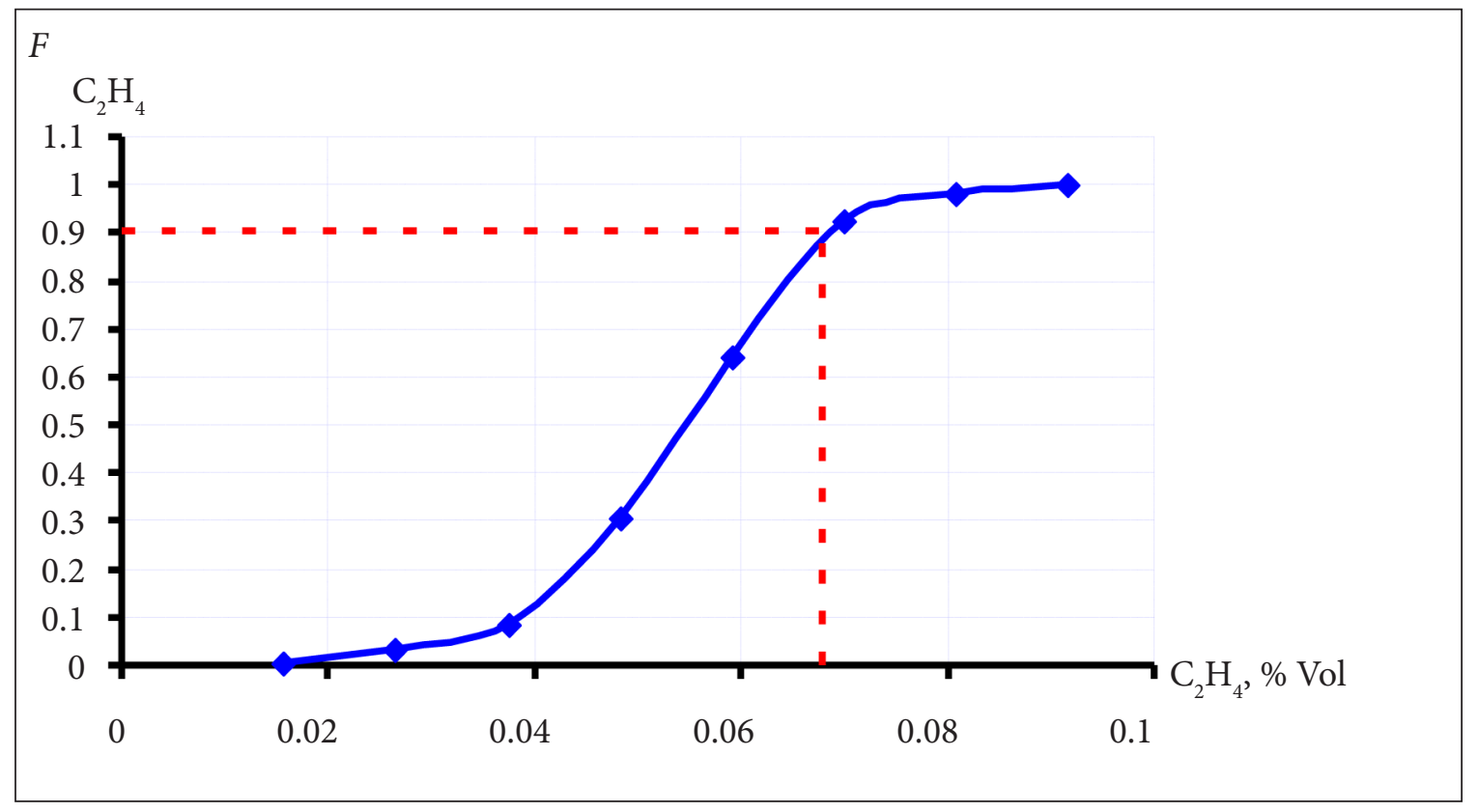

Fig. 1. Determination of the typical concentration of ethylene based on the analysis of integrated distribution functions

Ta ble 1. Typical values of gas concentrations obtained from the results of DGA transformers of a leaky design TRDN-110 kV, oil-filled mark TKp, based on the analysis of integrated distribution functions

\begin{tabular}{c|c|c|c|c}
\hline \multicolumn{5}{c}{ Dissolved gases in oil } \\
\hline Methane $\left(\mathrm{CH}_{4}\right)$ & Ethane $\left(\mathrm{C}_{2} \mathrm{H}_{6}\right)$ & Ethylene $\left(\mathrm{C}_{2} \mathrm{H}_{4}\right)$ & Acetylene $\left(\mathrm{C}_{2} \mathrm{H}_{2}\right)$ & Hydrogen $\left(\mathrm{H}_{2}\right)$ \\
\hline 0.0061 & 0.0032 & 0.0068 & 0.00016 & 0.0027 \\
\hline
\end{tabular}


Table 2. Values of scale and shape parameters for serviceable transformers of leaky design TRDN-25 MVA, $110 \mathrm{kV}$ and for transformers with developing defects

\begin{tabular}{|c|c|c|c|c|}
\hline \multirow{3}{*}{ Gas } & \multicolumn{4}{|c|}{ Transformers condition } \\
\hline & \multicolumn{2}{|c|}{ Normal } & \multicolumn{2}{|c|}{ Defective } \\
\hline & $a$ & $\beta$ & $a$ & $\beta$ \\
\hline Hydrogen $\left(\mathrm{H}_{2}\right)$ & 0.0017 & 1.89445 & 0.055464 & 2.503356 \\
\hline Methane $\left(\mathrm{CH}_{4}\right)$ & 0.00388 & 3.10723 & 0.041635 & 2.194290 \\
\hline Ethane $\left(\mathrm{C}_{2} \mathrm{H}_{6}\right)$ & 0.003412 & 2.741809 & 0.030929 & 2.421890 \\
\hline Ethylene $\left(\mathrm{C}_{2} \mathrm{H}_{4}\right)$ & 0.00494 & 3.415061 & 0.065647 & 2.115252 \\
\hline Acetylene $\left(\mathrm{C}_{2} \mathrm{H}_{2}\right)$ & 0.000470 & 4.420299 & 0.019442 & 1.761373 \\
\hline
\end{tabular}

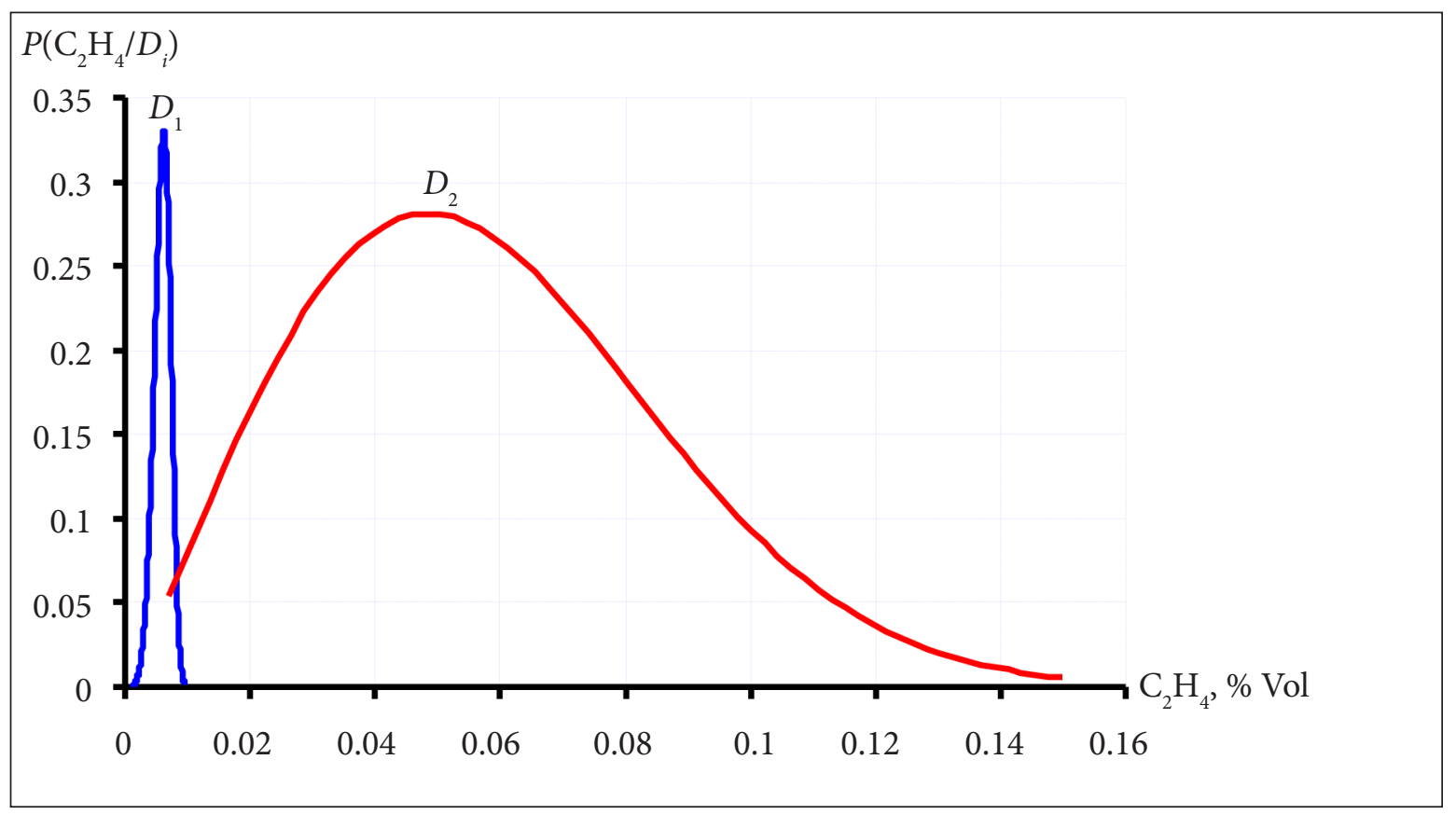

Fig. 2. Density of theoretical distributions of ethylene concentration for serviceable $\left(D_{1}\right)$ and defective $\left(D_{2}\right)$ state transformers of a leaky design TRDN-25 MVA, $110 \mathrm{kV}$

second kind (it is decided that the defective transformer is in good condition) is much higher than the price of the error of the first kind (a decision is made about the presence of a defect in a working transformer), then to determine the boundary values of the gas concentrations the criterion of a minimum of average risk is used. We determine that the decision on the working condition of the transformer is adopted if the concentrations of all gases do not exceed the corresponding boundary values. If the concentration of at least one gas exceeds the corresponding boundary value, then a decision is made about the presence of a defect.

The expression for determining the average risk [12] in the diagnosis of the complex of fea- tures, taking into account that the correct decisions are not encouraged, can be represented as:

$$
R=C_{21} P_{1} P_{21}+C_{12} P_{2} P_{12}
$$

where $P_{1}$ is probability of a defect-free state of the transformer (determined by preliminary statistical data), $P_{2}$ is probability of occurrence of a defect in the transformer (determined by preliminary statistical data), $P_{21}$ is probability that in a defect-free transformer gas concentrations exceed the boundary values, $P_{12}$ is probability that in the presence of a defect in the transformer, the concentration of gases will be below the boundary values, $C_{21}$ is conditional price of a 
false alarm, and $C_{12}$ is conditional price of crossing targets.

The values of the probabilities of erroneous decisions in the diagnosis of equipment by the content of five gases $[9,10]$ can be represented as:

The probability of an error of the first kind (the probability that in good transformers the concentration of one, two, three, four or all five gases exceeds the boundary values) can be represented as:

$$
\begin{aligned}
& P_{21}=\left[\int_{\mathrm{CH}_{4 b}}^{\infty} \frac{\beta_{\mathrm{CH}_{4}}}{\alpha_{\mathrm{CH}_{4}}{ }^{\beta_{\mathrm{CH}_{4}}}} \cdot \mathrm{CH}_{4}{ }^{\beta_{\mathrm{CH}_{4}}-1} \cdot e^{-\left(\frac{\mathrm{CH}_{4}}{\alpha_{\mathrm{CH}}}\right)^{\beta_{\mathrm{CH}}}} d \mathrm{CH}_{4} .\right. \\
& \cdot \int_{\mathrm{C}_{2} \mathrm{H}_{4(0)}}^{\mathrm{C}_{2} \mathrm{H}_{4 b}} \frac{\beta_{\mathrm{C}_{2} \mathrm{H}_{4}}}{\alpha_{\mathrm{C}_{2} \mathrm{H}_{4}}{ }^{\beta_{\mathrm{C}_{2} \mathrm{H}_{4}}}} \cdot \mathrm{C}_{2} \mathrm{H}_{4}{ }^{\beta_{\mathrm{C}_{2} \mathrm{H}_{4}}-1} \cdot e^{-\left(\frac{\mathrm{C}_{2} \mathrm{H}_{4}}{\alpha_{\mathrm{C}_{2} \mathrm{H}_{4}}}\right)^{\beta_{\mathrm{C}_{2} \mathrm{H}_{4}}}} d \mathrm{C}_{2} \mathrm{H}_{4} \cdot \\
& \cdot \int_{\mathrm{C}_{2} \mathrm{H}_{6}}^{\mathrm{C}_{2} \mathrm{H}_{66}} \frac{\beta_{\mathrm{C}_{2} \mathrm{H}_{6}}}{\alpha_{\mathrm{C}_{2} \mathrm{H}_{6}}{ }_{\mathrm{C}_{2} \mathrm{H}_{6}}} \cdot \mathrm{C}_{2} \mathrm{H}_{6}{ }^{\beta_{\mathrm{C}_{2} \mathrm{H}_{6}}{ }^{-1}} \cdot e^{-\left(\frac{\mathrm{C}_{2} \mathrm{H}_{6}}{\alpha_{\mathrm{C}_{2} \mathrm{H}_{6}}}\right)^{\beta_{2} \mathrm{H}_{2} \mathrm{H}_{6}}} d \mathrm{C}_{2} \mathrm{H}_{6} \cdot \\
& \cdot \int_{\mathrm{C}_{2} \mathrm{H}_{2(0)}}^{\mathrm{C}_{2} \mathrm{H}_{2 b}} \frac{\beta_{\mathrm{C}_{2} \mathrm{H}_{2}}}{\alpha_{\mathrm{C}_{2} \mathrm{H}_{2}} \beta_{\mathrm{C}_{2} \mathrm{H}_{2}}} \cdot \mathrm{C}_{2} \mathrm{H}_{2}{ }^{\beta_{\mathrm{C}_{2} \mathrm{H}_{2}}-1} \cdot e^{-\left(\frac{\mathrm{C}_{2} \mathrm{H}_{2}}{\alpha_{\mathrm{C}_{2} \mathrm{H}_{2}}}\right)^{\beta_{\mathrm{C}_{2} \mathrm{H}_{2}}}} d \mathrm{C}_{2} \mathrm{H}_{2} \cdot \\
& \left.\cdot \int_{\mathrm{H}_{2(0)}}^{\mathrm{H}_{2 b}} \frac{\beta_{\mathrm{H}_{2}}}{\alpha_{\mathrm{H}_{2}} \beta_{\mathrm{H}_{2}}} \cdot \mathrm{H}_{2}{ }^{\beta_{\mathrm{H}_{2}}-1} \cdot e^{-\left(\frac{\mathrm{H}_{2}}{\alpha_{\mathrm{H}_{2}}}\right)^{\beta_{\mathrm{H}_{2}}}} d \mathrm{H}_{2}\right]+\ldots+ \\
& +\ldots+\left[\int_{\mathrm{CH}_{4 b}}^{\infty} \frac{\beta_{\mathrm{CH}_{4}}}{\alpha_{\mathrm{CH}_{4}} \beta_{\mathrm{CH}_{4}}} \cdot \mathrm{CH}_{4}{ }^{\beta_{\mathrm{CH}_{4}}-1} \cdot e^{-\left(\frac{\mathrm{CH}_{4}}{\alpha_{\mathrm{CH}}}\right)^{\beta_{\mathrm{CH}}}} d \mathrm{CH}_{4} .\right. \\
& \cdot \int_{\mathrm{C}_{2} \mathrm{H}_{6 b}}^{\infty} \frac{\beta_{\mathrm{C}_{2} \mathrm{H}_{6}}}{\alpha_{\mathrm{C}_{2} \mathrm{H}_{6}} \beta_{\mathrm{C}_{2} \mathrm{H}_{6}}} \cdot \mathrm{C}_{2} \mathrm{H}_{6}{ }^{\beta_{\mathrm{C}_{2} \mathrm{H}_{6}}-1} \cdot e^{-\left(\frac{\mathrm{C}_{2} \mathrm{H}_{6}}{\alpha_{\mathrm{C}_{2} \mathrm{H}_{6}}}\right)^{\beta_{\mathrm{C}_{2} \mathrm{H}_{6}}}} d \mathrm{C}_{2} \mathrm{H}_{6} \cdot \\
& \cdot \int_{\mathrm{C}_{2} \mathrm{H}_{4 b}}^{\infty} \frac{\beta_{\mathrm{C}_{2} \mathrm{H}_{4}}}{\alpha_{\mathrm{C}_{2} \mathrm{H}_{4}} \beta_{\mathrm{C}_{2} \mathrm{H}_{4}}} \cdot \mathrm{C}_{2} \mathrm{H}_{4}{ }^{\beta_{\mathrm{C}_{2} \mathrm{H}_{4}}-1} \cdot e^{-\left(\frac{\mathrm{C}_{2} \mathrm{H}_{4}}{\alpha_{\mathrm{C}_{2} \mathrm{H}_{4}}}\right)^{\mathrm{C}_{2} \mathrm{H}_{4}}} d \mathrm{C}_{2} \mathrm{H}_{4} \cdot \\
& \cdot \int_{\mathrm{C}_{2} \mathrm{H}_{2 b}}^{\infty} \frac{\beta_{\mathrm{C}_{2} \mathrm{H}_{2}}}{\alpha_{\mathrm{C}_{2} \mathrm{H}_{2}}{ }_{\mathrm{C}_{2} \mathrm{H}_{2}}} \cdot \mathrm{C}_{2} \mathrm{H}_{2}{ }^{\beta_{\mathrm{C}_{2} \mathrm{H}_{2}}-1} \cdot e^{-\left(\frac{\mathrm{C}_{2} \mathrm{H}_{2}}{\alpha_{\mathrm{C}_{2} \mathrm{H}_{2}}}\right)^{\beta_{\mathrm{C}_{2} \mathrm{H}_{2}}}} d \mathrm{C}_{2} \mathrm{H}_{2} \cdot \\
& \left.\cdot \int_{\mathrm{H}_{2 b}}^{\infty} \frac{\beta_{\mathrm{H}_{2}}}{\alpha_{\mathrm{H}_{2}} \beta_{\mathrm{H}_{2}}} \cdot \mathrm{H}_{2}{ }^{\beta_{\mathrm{H}_{2}}-1} \cdot e^{-\left(\frac{\mathrm{H}_{2}}{\alpha_{\mathrm{H}_{2}}}\right)^{\beta_{\mathrm{H}_{2}}}} d \mathrm{H}_{2}\right] \text {, }
\end{aligned}
$$

where $\mathrm{CH}_{4}, \mathrm{C}_{2} \mathrm{H}_{4}, \mathrm{C}_{2} \mathrm{H}_{2}, \mathrm{C}_{2} \mathrm{H}_{6}, \mathrm{H}_{2}$ are values of gases concentrations; $\mathrm{CH}_{4 b}, \mathrm{C}_{2} \mathrm{H}_{4 b}, \mathrm{C}_{2} \mathrm{H}_{2 b}, \mathrm{C}_{2} \mathrm{H}_{6 b}$, $\mathrm{H}_{2 b}$ are boundary values of gases concentration; $\mathrm{CH}_{4(0)}, \mathrm{C}_{2} \mathrm{H}_{4(0)}, \mathrm{C}_{2} \mathrm{H}_{2(0)}, \mathrm{C}_{2} \mathrm{H}_{6(0)}, \mathrm{H}_{2(0)}$ are lower limit of detection of the respective gas chromatograph; $\alpha_{\mathrm{CH}_{4}}, a_{\mathrm{C}_{2} \mathrm{H}_{4}}, a_{\mathrm{C}_{2} \mathrm{H}_{2}}, a_{\mathrm{C}_{2} \mathrm{H}_{6}}, a_{\mathrm{H}_{2}}$ are scale parameters of the Weibull distribution law, for the concentrations of defect-free transformers; $\beta_{\mathrm{CH}_{4} \text { ' }}$ $\beta_{\mathrm{C}_{2} \mathrm{H}_{4}}, \beta_{\mathrm{C}_{2} \mathrm{H}_{2}}, \beta_{\mathrm{C}_{2} \mathrm{H}_{6}}, \beta_{\mathrm{H}_{2}}$ are shape parameters of the Weibull distribution law, for gas concentrations in the defect-free transformers.

The probability of an error of the second kind (the probability that when the defect develops the concentrations of all five gases will be less than the boundary values) can be represented as:

$$
\begin{aligned}
& P_{12}=\left[\int_{\mathrm{CH}_{4(0)}}^{\mathrm{CH}_{4 b}} \frac{\gamma_{\mathrm{CH}_{4}}}{\eta_{\mathrm{CH}_{4}}{ }_{\mathrm{CH}_{4}}} \cdot \mathrm{CH}_{4}{ }^{\gamma_{\mathrm{CH}}-1} \cdot e^{-\left(\frac{\mathrm{CH}_{4}}{\eta_{\mathrm{CH}_{4}}}\right)^{\gamma_{\mathrm{CH}} 4}} d \mathrm{CH}_{4} \cdot\right. \\
& \cdot \int_{\mathrm{C}_{2} \mathrm{H}_{6(0)}}^{\mathrm{C}_{2} \mathrm{H}_{6_{b}}} \frac{\gamma_{\mathrm{C}_{2} \mathrm{H}_{6}}}{\eta_{\mathrm{C}_{2} \mathrm{H}_{6}}{ }^{\gamma \mathrm{C}_{2} \mathrm{H}_{6}}} \cdot \mathrm{C}_{2} \mathrm{H}_{6}{ }^{\gamma_{\mathrm{C}_{2}} \mathrm{H}_{6}-1} \cdot e^{-\left(\frac{\mathrm{C}_{2} \mathrm{H}_{6}}{\eta_{\mathrm{C}_{2}} \mathrm{H}_{6}}\right)^{\gamma_{2} \mathrm{C}_{2} \mathrm{H}_{6}}} d \mathrm{C}_{2} \mathrm{H}_{6} \cdot \\
& \cdot \int_{\mathrm{C}_{2} \mathrm{H}_{4(0)}}^{\mathrm{C}_{2} \mathrm{H}_{4 b}} \frac{\gamma_{\mathrm{C}_{2} \mathrm{H}_{4}}}{\eta_{\mathrm{C}_{2} \mathrm{H}_{4}}{ }^{\gamma_{2} \mathrm{H}_{4}}} \cdot \mathrm{C}_{2} \mathrm{H}_{4}{ }^{{ } \mathrm{C}_{2} \mathrm{H}_{4}-1} \cdot \mathrm{e}^{-\left(\frac{\mathrm{C}_{2} \mathrm{H}_{4}}{\eta_{\mathrm{C}_{2} \mathrm{H}_{4}}}\right)^{\gamma_{2} \mathrm{H}_{4}}} d \mathrm{C}_{2} \mathrm{H}_{4} \cdot \\
& \cdot \int_{\mathrm{C}_{2} \mathrm{H}_{2(0)}}^{\mathrm{C}_{2} \mathrm{H}_{2 b}} \frac{\gamma_{\mathrm{C}_{2} \mathrm{H}_{2}}}{\eta_{\mathrm{C}_{2} \mathrm{H}_{2}} \gamma_{\mathrm{C}_{2} \mathrm{H}_{2}}} \cdot \mathrm{C}_{2} \mathrm{H}_{2}{ }^{\gamma_{\mathrm{C}_{2} \mathrm{H}_{2}-1}} \cdot e^{-\left(\frac{\mathrm{C}_{2} \mathrm{H}_{2}}{\eta_{\mathrm{C}_{2} \mathrm{H}_{2}}}\right)^{\gamma_{\mathrm{C}_{2} \mathrm{H}_{2}}}} d \mathrm{C}_{2} \mathrm{H}_{2} \cdot \\
& \left.\cdot \int_{\mathrm{H}_{2(0)}}^{\mathrm{H}_{2 b}} \frac{\gamma_{\mathrm{H}_{2}}}{\eta_{\mathrm{H}_{2}} \gamma_{\mathrm{H}_{2}}} \cdot \mathrm{H}_{2}{ }^{\gamma_{\mathrm{H}_{2}}-1} \cdot e^{-\left(\frac{\mathrm{H}_{2}}{\eta_{\mathrm{H}_{2}}}\right)^{\gamma_{\mathrm{H}_{2}}}} d \mathrm{H}_{2}\right] \text {, }
\end{aligned}
$$

where $\eta_{\mathrm{CH}_{4}}, \eta_{\mathrm{C}_{2} \mathrm{H}_{4}}, \eta_{\mathrm{C}_{2} \mathrm{H}_{2}}, \eta_{\mathrm{C}_{2} \mathrm{H}_{2}}, \eta_{\mathrm{H}_{2}}$ are scale parameters of the Weibull distribution law, for concentrations of defective transformers; $\gamma_{\mathrm{CH}_{4},}, \gamma_{\mathrm{C}_{2} \mathrm{H} 4^{\prime}}$ $\gamma_{\mathrm{C}_{2} \mathrm{H}_{2}}, \gamma_{\mathrm{C}_{2} \mathrm{H}_{2}}, \gamma_{\mathrm{H}_{2}}$ are shape parameters of the Weibull distribution law, for defective gas concentrations in transformers.

To determine the boundary values of gas concentrations, an approach based on gradient descent methods was used, in particular, the Nelder-Mead method [13]. The Nelder-Mead method also known as the deformable polyhedron method allows one to obtain the values of variables that ensure the minimum of a certain function. 
To determine the boundary values, the minimum risk method was implemented in the form of the author's program "BOUNDARY". The "BOUND$A R Y$ " program allows not only to determine the boundary values of diagnostic signs for different distribution laws, but also calculates the probability values of correct and erroneous decisions, as well as the risk values. By analogy with $[9,10]$, the calculation of the boundary values was carried out for $P_{2}=0.05$ d.u., $P_{1}=0.95$ d.u. and the price ratio of the erroneous solutions $\mathrm{C}=\mathrm{C}_{12} / \mathrm{C}_{21}=10000$. As parameters of distribution laws, for defect-free and defect states, the values given in Table 2 were used. The values of concentrations of gases, which were calculated using the program "BOUNDARY", are given in Table 3.

\section{COMPARATIVE RISK ANALYSIS}

Comparing the values given in Table 1 and Table 3 it is easy to see that the boundary values of the concentrations of gases that are obtained for the same data by different methods substantially differ. Consequently, their use will be accompanied by different risk values. To assess the reliability of the decision, an analysis was made of the mean risk [14], which is accompanied by the use of the obtained boundary and typical concentrations. The values of the probabilities of correct $\left(P_{11}\right.$ and $\left.P_{22}\right)$ and erroneous solutions $\left(P_{21}\right.$ and $\left.P_{12}\right)$, as well as the risk values obtained using typical and boundary values of gas concentrations are given in Table 4.

Table 3. Boundary gas concentrations obtained from the results of DGA transformers TRDN-110 kV, oil-filled mark TKp, the method of minimum risk

\begin{tabular}{c|c|c|c|c}
\hline \multicolumn{5}{c}{ Dissolved gases in oil } \\
\hline Methane $\left(\mathrm{CH}_{4}\right)$ & Ethane $\left(\mathrm{C}_{2} \mathrm{H}_{6}\right)$ & Ethylene $\left(\mathrm{C}_{2} \mathrm{H}_{4}\right)$ & Acetylene $\left(\mathrm{C}_{2} \mathrm{H}_{2}\right)$ & Hydrogen $\left(\mathrm{H}_{2}\right)$ \\
\hline 0.009 & 0.00884 & 0.0107 & 0.00086 & 0.00663 \\
\hline
\end{tabular}

Table 4. The values of the probabilities of errors of the first and second kind and the probabilities of the correct solutions, as well as the values of the risks when using the boundary values of the gas concentrations which were obtained by different methods

\begin{tabular}{|c|c|c|c|c|c|c|}
\hline \multirow[t]{2}{*}{ No. } & \multirow[t]{2}{*}{ Method/Standard } & \multicolumn{4}{|c|}{$\begin{array}{l}\text { Values of the probabilities of correct and erroneous } \\
\text { solutions }\end{array}$} & \multirow[t]{2}{*}{$\boldsymbol{R}$} \\
\hline & & $P_{11}$ & $P_{21}$ & $P_{22}$ & $P_{12}$ & \\
\hline 1. & $\begin{array}{l}\text { The method of integral functions for } \\
\text { transformers of a leaky design } \\
\text { TRDN-110 kV, oil-filled mark TKp }\end{array}$ & 0.00410 & 0.99590 & 0.999999 & $3.1 \cdot 10^{-12}$ & 0.946 \\
\hline 2. & $\begin{array}{l}\text { The minimum risk method for transfor- } \\
\text { mers of a leaky design of TRDN-110 kV, } \\
\text { oil-filled mark TKp }\end{array}$ & 0.99999 & $5.3 \cdot 10^{-6}$ & 0.999999 & $3.6 \cdot 10^{-8}$ & $2.3 \cdot 10^{-5}$ \\
\hline 3. & $\begin{array}{l}\text { The minimum risk method for transfor- } \\
\text { mers of a leaky design of TDTN-110 kV, } \\
\text { oil-filled mark T-1500 [9] }\end{array}$ & 0.99986 & 0.00014 & 0.999992 & $7.3 \cdot 10^{-6}$ & 0.00381 \\
\hline 4. & IEC 60599 [1] & 0.99999 & $6.2 \cdot 10^{-7}$ & 0.999985 & $1.4 \cdot 10^{-5}$ & 0.00723 \\
\hline 5. & IEEE Std C57.104 (USA) [2] & 0.99999 & $1.5 \cdot 10^{-5}$ & 0.999377 & $6.2 \cdot 10^{-4}$ & 0.311 \\
\hline 6. & Dornenburg [3] & 0.42536 & 0.57464 & 0.999999 & $3.7 \cdot 10^{-9}$ & 0.546 \\
\hline 7. & SOU-N EE 46.501:2006 (Ukraine) [4] & 0.99999 & $1.5 \cdot 10^{-5}$ & 0.999999 & $7.3 \cdot 10^{-7}$ & 0.00038 \\
\hline 8. & $\begin{array}{l}\text { RD 153.34.0-46.302-00 } \\
\text { (Russia) [5] }\end{array}$ & 0.94221 & 0.05779 & 0.999999 & $3.4 \cdot 10^{-8}$ & 0.0549 \\
\hline 9. & Duval [15] & 0.00069 & 0.99931 & 0.999999 & $4.5 \cdot 10^{-10}$ & 0.9493 \\
\hline 10. & EDF (France) [16] & $9.1 \cdot 10^{-6}$ & 0.99999 & 0.999999 & $1.1 \cdot 10^{-9}$ & 0.9499 \\
\hline 11. & BBC (Switzerland) [16] & 0.07594 & 0.924051 & 0.999999 & $1.4 \cdot 10^{-9}$ & 0.877 \\
\hline
\end{tabular}


Table 4. (continued)

\begin{tabular}{|c|c|c|c|c|c|c|}
\hline \multirow{2}{*}{ No. } & \multirow{2}{*}{ Method/Standard } & \multicolumn{4}{|c|}{$\begin{array}{l}\text { Values of the probabilities of correct and erroneous } \\
\text { solutions }\end{array}$} & \multirow{2}{*}{$\boldsymbol{R}$} \\
\hline & & $\boldsymbol{P}_{11}$ & $\boldsymbol{P}_{21}$ & $\boldsymbol{P}_{22}$ & $\boldsymbol{P}_{12}$ & \\
\hline 12. & OY STROMBERG (Finland) [16] & 0.99998 & $1.5 \cdot 10^{-5}$ & 0.999998 & $1.5 \cdot 10^{-6}$ & $7.7 \cdot 10^{-4}$ \\
\hline 13. & HYDRO QUEBEC (Canada) [16] & 0.01742 & 0.98257 & 0.999999 & $6.8 \cdot 10^{-10}$ & 0.933 \\
\hline 14. & SECR (Japan) [16] & $4.9 \cdot 10^{-5}$ & 0.99995 & 0.999999 & $7.1 \cdot 10^{-7}$ & 0.950 \\
\hline 15. & California State University (USA) [16] & 0.65772 & 0.34228 & 0,999998 & $2.5 \cdot 10^{-6}$ & 0.326 \\
\hline 16. & Northern Technology \& Testing (USA) [17] & 0.65578 & 0.34422 & 0.999999 & $8.8 \cdot 10^{-7}$ & 0.327 \\
\hline 17. & MSZ-09-00.0352 (Malaysia) [18] & 0.01104 & 0.98896 & 0.999999 & $5.7 \cdot 10^{-11}$ & 0.939 \\
\hline 18. & Energopomiar (Poland) [19] & 0 & 1.0 & 0.99732 & 0.00268 & 1.340 \\
\hline
\end{tabular}

For completeness of analysis, Table 4 lists the risk values that could arise when diagnosing the transformers under analysis using boundary values that are recommended by known standards or obtained for another type of equipment. As can be seen from the table, the use of typical values of gas concentrations obtained using integrated distribution functions is accompanied by one of the highest risk values.

Higher risk values occur when using the boundary values of gas concentrations recommended by standards Energopomiar (No. 18), SECR (No. 14), EDF (No. 10) and Duval (No. 9). Boundary values which are recommended by other standards provide a lower risk value than typical values obtained by the method of integral functions. Obviously, the lowest risk value is provided by the boundary concentrations obtained by the minimum risk method. However, by comparing the risk values calculated for the boundary concentrations of gases obtained by the minimum risk method for equipment filled with different types of oil (No. 2 and No. 3) it is easy to see that the use of the boundary values of the oil-filled T-1500 (transformer oil obtained from low-sulfur oils by the method of sulfuric acid and selective purification) for transformers filled with oil TKP leads to a significant increase in risks. Thus, in order to minimize the risk value, and as a consequence of ensuring minimum economic damage, using only the minimum risk method is not enough. The boundary values of gas concentrations must be determined taking into account the type of protection of oils, oil type, loading of transformers and other factors.

\section{CONCLUSIONS}

The above results show that the use of the integral function method to determine typical values of gas concentrations leads to a significant increase in the mean risk, compared to the risks that accompany the use of the boundary values of gas concentrations recommended by the current standards. This is due to the fact that in determining the values of typical gas concentrations, gas distributions in equipment with developing defects are not taken into account. In connection with these, in order to reduce the risks in the diagnosis of oil-filled equipment, according to the results of DGA, the boundary values of gas concentrations should be determined using statistical methods, in particular, the minimum risk method. At the same time, it should be borne in mind that to ensure the minimum value of risk, it is not enough to use only the methods of statistical decisions. The minimum risk value, when diagnosing high-voltage transformers based on the analysis of dissolved gases in the oil, is provided by the boundary values of concentrations obtained by the minimum risk method, taking into account the type of protection of oils, grade of oil, loading of transformers and other factors.

Received 13 July 2018 Accepted 20 September 2018

\section{References}

1. IEC Publication 60599, Interpretation of the analysis of gases in transformer and other oil 
med electrical equipment in \&, Geneva, Switzerland, 1999.

2. IEEE Guide for the Interpretation of Gases Generated in Oil-Immersed Transformers, IEEE StandARCd C57.104-2008, Feb. 2009.

3. Dornenburg E., Strittmater W. Monitoring oil cooling transformers by gas analysis. Brown Boveri Review. 1974. Vol. 61. P. 238-274.

4. SOU-N EE 46.501: Diagnosis oil-filled transformer equipment based on the results of chromatographic analysis of free gas with gas relay selected, i gases dissolved in insulating oil. Kiïv, 2007.

5. RD 153-34.0-46.302-00: Guidelines for the diagnosis of developing defects in transformer equipment based on the results of the chromatographic analysis of gases dissolved in oil. Moskva, 2001.

6. Davydenko I. V. Determination of permissible values of controllable parameters of oil-filled equipment, based on the observed data array. Electricity. 2009. No. 6. P. 10-21.

7. Zakharov A. V. Detection of defects in oil-filled power transformers as a procedure for testing statistical hypotheses. New in the Russian Electric Power Industry. 2001. No. 2. P. 22-28.

8. Levin M. N. Statistical method of defect recognition in power transformers for their maintenance according to their state. Industrial Power Engineering. 2013. No. 8. P. 37-41.

9. Shutenko O. V. Determining the limit concentrations of gases dissolved in oil using the minimal risk method. Electricity. 2017. No. 8. P. 50-60.

10. Shutenko O. V. Determine the boundary value of the concentration of gases dissolved in oil of method minimum risk. 2017 IEEE First Ukraine Conference on Electrical and Computer Engineering (UKRCON), May 29-June 2, Kyiv, Ukraine, 2017. P. 468-472.

11. Shutenko O. V., Baklaj D. N. Analysis of gases concentration distribution laws, dissolved in oil of high voltage transformers unpressurized of execution. Bulletin of the National Technical University "KhPI". Collection of scientific papers. Series: Power reliability and energy efficiency, Kharkov: NTU "KhPI". 2014. No. 24(067). P. 102-117.

12. Birger I. A. Technical Diagnostics. Moskva: Mechanical Engineering, 1978. 240 p.

13. Chernoruckij I. G. Decision-Making Methods. St. Petersburg: BHV-Petersburg, 2005. 416 p.

14. Abramov V. B., Shutenko O. V., Baklaj D. N. Comparative analysis of average risk using the recommended limit concentration of gases dissolved in oil for detecting defects in transformers 110 kV. Science News of NTUU "KPI". 2014. No. 6(98). P. 16-26.

15. Saranya S., Mageswari U., Roy N., Sudha R. Comparative study of various dissolved gas analysis methods to diagnose transformer faults. International Journal of Engineering Research and Applications (IJERA). 2013. Vol. 3. Issue 3. P. 592-595.

16. Gray I. A. R. A Guide Transformer Oil Analysis, Transformer Chemistry Services. <htpp:// www.satcs.co.za/ Transformer Oil Analysis.pdf> $(2 / 2013)$.

17. DiGiorgio J. B. Dissolved gas analysis of mineral oil insulating fluids. DGA Expert System: A Leader in Quality, Value and Experience. 2005. Vol. 1. P. 1-17.

18. Raisan A., Yaacob M. M., Alsaedi M. A. Faults diagnosis and assessment of transformer insulation oil quality: intelligent methods based on dissolved gas analysis a-review. International Journal of Engineering \& Technology. 2015. Vol. 4. No. 1. P. 54-60.

19. Alekseev B. A. Monitoring of Condition (Diagnostics) of Large Power Transformers. Moskva: Publishing house NTS ENAS, 2002. 216 p. 
Oleg Shutenko, Olena Proskurnia,

Volodymyr Abramov

\section{AUKŠTOS IৃTAMPOS TRANSFORMATORIŲ \\ DIAGNOSTIKOS SPRENDIMŲ, SUSIJUSIỤ SU \\ TIPINE IR RIBINE DUJŲ KONCENTRACIJA, RIZIKOS LYGINAMOJI ANALIZE்}

\section{Santrauka}

Straipsnio tyrimo teminè sritis - aukštos įtampos galios transformatorių eksploatacinis patikimumas. Siekiama mažinti transformatorių gedimų riziką, diagnozuojant transformatorių būklę pagal alyvoje ištirpusių dujų analizès rezultatus. Straipsnio tyrimo objektas yra dviejų diagnostikos metodų lyginamoji analizè. Šiais metodais nustatoma tipinė ir ribinė dujų koncentracija alyvoje. Lyginamas autorių teikiamas minimalios rizikos metodas ir praktikoje žinomas (kai kur standartizuotas) integralinių funkcijų metodas. Dujų ribinių koncentracijų, gautų integralinių funkcijų metodu ir minimalios rizikos metodu, analizè parodé, kad jos labai skiriasi, esant tiems patiems pradiniams duomenims. Taikant pastarąji metodą nustatomos mažiau rizikingos ribinès koncentracijos. Ši metodą rekomenduotina taikyti pirmiausia transformatoriams, dirbantiems ilgiau nei jų nustatytas darbo amžius.

Raktažodžiai: diagnostika, transformatoriai, ištirpusių dujų analizè, ribinès ir tipinès koncentracijos, integralinès pasiskirstymo funkcijos, minimalios rizikos metodas, klaidingų ir teisingų sprendimų tikimybès 